\title{
Analysis of the Effect of E-Government Implementation on Quality of Information Towards Government to Government
}

\author{
Ilham Multama \\ Magister of Accounting \\ Andalas University \\ Sumatera Barat, Indonesia \\ multamailham@gamil.com
}

\author{
Asniati \\ Faculty of Economics \\ Andalas University \\ Sumatera Barat, Indonesia \\ asniati.bahari@gmail.com
}

\author{
Annisa Rahman \\ Faculty of Economics \\ Andalas University \\ Sumatera Barat, Indonesia \\ Annisaa.rahman@yahoo.com
}

\begin{abstract}
The purpose of this study is to analyzed the effect of e-Government application on the quality of information of a local government called Kabupaten Agam. This study also analyzed factors that influence e-Government implementation such as user resistance, organizational culture, management support, human resource competence, and information technology. The population in this study were all employees of the local government in Kabupaten Agam amounted to 6874 people. The sampling technique was purposive sampling. The total sample of 119 respondents. Research instrument used was questionnaire. Data were analyzed with Structural Equation Model (SEM) and Second Order Confirmatory Factor Analysis (CFA) with AMOS 22. The results showed that there is a positive and significant influence of human resource competence on the implementation of e-Government. However, there is no positive and significant influence on user resistance, organizational culture, management support, and information technology on eGovernement implementation. The results also show that there is a positive and significant influence of e-Government applications on information quality. Human resource competence is an important factor affecting the implementation of e-Government to produce good information quality at local government of Kabupaten Agam The better the implementation of e-Government through institutional and infrastructure will result in the quality of information that is relevant and tested. The results of this study will contribute to the improvement of information systems in the district government of kabupaten agam and science related to information systems.
\end{abstract}

Keyword-user resistance, organizational culture, management support, human resource competence, and information technology, e-Government, information quality

\section{INTRODUCTION}

The United Nations has published the EGDI (EGovernment Development Index) ranking based on a 2016 survey. In this year Indonesia ranked 116 EGDI, down 10 ratings compared to 2014 which ranked 106th. This condition is still far below the countries in Southeast Asia such as Malaysia (ranked 60th), Philippines (ranked 71), and Brunei Darussalam (ranked 83rd). This has certainly created a challenge for Indonesia to be able to improve the EGDI rankings in the years to come, in which the figures obtained are a reflection of the conditions of e-Government implementation to ensure that public institutions are more inclusive, effective, accountable and transparent [1]
Presidential Instruction (Instruction) no. 3 of 2003 on National Policy and Strategy of e-Government Development in Indonesia. The President has instructed every Governor and Regent / Mayor to take the necessary steps in accordance with their respective duties, functions and authorities for the implementation of national e-Government development.

The Government through the Ministry of Communications and Information Technology to implement e-Government Ranking Indonesia (PEGI) to look at the general condition of the implementation of e-Government in Indonesia. PEGI has been implemented since 2007 with the implementation phase of assessment, namely access to ministries / agencies, and provincial and district / city. The average value of national PEGI 2015 is at 2.7. For the ministerial level average value of 2.7 PEGI its first rating achieved by the Ministry of Finance, followed by the Ministry of Culture, Primary and Secondary Education ranked second and third in the Ministry of Foreign Affairs. While the average value of the national PEGI, LPNK level is achieved first by 2.7 by Statistics Agency for the Assessment and Application of Technology won the Geospatial Information Agency [2].

For the ministerial level average value of 2.7 PEGI its first rating achieved by the Ministry of Finance, followed by the Ministry of Culture, Primary and Secondary Education ranked second and third in the Ministry of Foreign Affairs. While the national average value of PeGI level of LPNK is the first 2.7 achieved by the Central Bureau of Statistics Agency for the Assessment and Application of Technology achieved by the Geospatial Information Agency In the meantime, the island of Sumatra is getting a bad factor in the implementation of e-Government in 2015 where there are provinces of South Sumatra, West Sumatera and Lampung. The development of e-Government implementation in the province is still incomplete. The things that will be applied in the implementation of providing better information to the community [2].

Meanwhile, the island of Sumatra has a poor assessment on the implementation of e-Government in 2015 where there are Provinces of South Sumatra, West Sumatra, and Lampung. The development of e-Government implementation in the province is still getting the Less appraisal so that this will result in the implementation of bad governance which then 
has implication to the public service in giving better information to the society.

At the district government level is Kabupaten Agam, some information systems / applications by the Regional Office. each regional office has different information systems in the service environment and information exchange between agencies will affect the quality of information. As the search for Baltzan that Integrity Information system is a measure of the quality of information [3].

Agarwal [4] divides the application of e-Government into five levels, the higher the level, the more complex the problems will be faced. The information system in Kabupaten Agam for each regional office has its own separate and interagency system. In addition, the regional office also has a website / application each to provide services through information systems. Based on the above, the application of information system in Agam Regency entered into the second level. But to go to the third level of information systems integration or known as Government to Government (G2G), the implementation of e-Government on the first and second level should be implemented or implemented properly.

Integration of the system will rapidly reduce the cost, time, and resources needed to create results and simultaneously improve the quality, reliability, and affordability [5]. Integration of Information Systems aims to combine the previously separate information systems with the aim of an information resource that is more complete and thorough for an organization [6].

User resistance is one of the problems in an integrated information system changes such as e-Government. There might be internal (individuals) who are used to the old system and are reluctant to follow the changes [7].

Cultural norms and patterns of behavior of individuals play a role in how citizens and policy makers using the technology. Because culture plays an important role in the views of individuals, many people resist change and adopt new technologies slowly and with great consideration [8]. Hackney \& Jones identified that improving working relationships between internal departments and external agencies, and adopting a corporate approach as the key to eGovernment success[9]. To achieve this, it is felt that major cultural changes are needed. Organizational development should be included in the implementation process so that internal cultural change is accommodated.

The implementation of e-Government requires support from the highest levels of government for successful implementation. Top management support refers to the commitment of top management to provide a positive environment that encourages participation in e-Government applications. Therefore, it plays an important role in the adoption and application of e-Government [10].

Analysis of awareness, training and capacity building, which are the two dominant themes under the Human aspect, revealed that the lack of ICT skills in the public sector is a major challenge for e-government initiatives [11]. The challenge of e-Government is the lack of ICT skills. This is a particular problem in developing countries, where lack of qualified staff and inadequate human resource training has been a problem for many years [12].
Many developing countries, even if they have the will, do not have the necessary infrastructure to immediately deploy e-Government services throughout their region [13]. IT standards that mean specifications for hardware and software, to help people manage and use technology, a single integrated gateway model for e-Government adoption is expected to provide access to information and services that require public sector governments to share information, knowledge, participate positively, and collaborate to provide eGovernment services [14].

Based on the explanation above we can conclude that the implementation of e-Government towards $G 2 G$ has several challenges that must be considered by every local government that implement an integrated system between each OPD (Organization of the Region) who exchange information to provide quality information and good service. Allegedly there is a resistance factor system users, organizational culture, management support, human resources and information technology and infrastructure that must be prepared first agara implementation of e-Government goes well for the next stage.

\section{LITERATURE REVIEW}

\section{a. Information Quality}

Jogiyanto [15] has explained information is data that is processed into a form that is more useful and more meaningful for those who receive it, and describes an event and real unity (fact and entity) used for decision making.

The quality of information is the level at which information has the characteristics, content, form and time that give it to certain end users [16].

1) Information Quality Indicators

According Jogiyanto [15] quality information from an information system depends on three things :
a) Accurate.
b) Just in time.
c) Relevant

To be useful, the information must be classified as follows [17]:
a) Relevant,
b) Trustworthy.
c) Complete
d) Timely
e) Easy to understand
f) Can be tested
g) Truth independently

2) Factors Affecting Information Quality

Dellon \& McLean [18] said the success of an information system to measure the output generated by the system. Furthermore, DeLone and McLean [18] say that the success of the model includes six components of information system success ie, system quality, information quality, usability, user satisfaction, individual, organization.

Baltzan [3] disclosing information is a measure of the quality of information. Integrity constraints are rules that help Ensure information quality. Factors affecting the adoption of e-government websites are quality of information, system 
quality and service quality. Quality information with information generated system [19].

\section{b. E- Government}

Heeks [20] defines e-Government as follows: "Activities undertaken by the government using Information Technology (IT) to provide services to the community". From this definition, we can see that the main goal of e-Government is to improve the efficiency and quality of services. According to Heeks, almost all government institutions in the world are inefficient, especially in developing countries.

In international rules, The World Bank Group [21], defines e-government is the E-Government Refers to the use by government agencies of information technologies (such as Wide Area Networks, the Internet, and mobile computing) that have the ability to transform relations with citizens, businesses, and other arms of government.

From this very general definition, it can be seen that the eGovernment refers to the use of information technology in government agencies or public institutions. The aim is that the relationships of governance involving the government, private and community can be created such that it is more efficient and effective. In much of the literature, eGovernment is also associated with the concept of online digital government or government and is usually discussed in the context of transformational government. The essence of this understanding is the use of Internet technology that is expected to be a means to accelerate the exchange of information, providing means of service and transaction activities with citizens, business people and of course the government it self.

The e-Government measurement indicator is

(22):
a) Policy
b) Institutions
c) Infrastructure
d) Applications
e) Planning

\section{c. Effect of User Resistance Against Implementation of e- Government}

Resistant behavior is demonstrated by the user of the system in an attempt to refuse to use the new information system. This behavior may vary and may be caused by many factors, such as a person's reluctance to use the new system because he does not understand, is comfortable with the existing system and is not well trained to use the new system.

User resistance is one of the problems in the changing eGovernment information systems. The possibility that there are internal parties (individuals) who are familiar with the old system and are reluctant to follow the changes with the integration of systems between government agencies will certainly change and exchange information.

The user resistance measurement indicator is : [7]:
a) Perceived Value
b) Switching Cost
c) Switching Benefits
d)Favorable Colleague Opinion
e) Self Confidence to Change
f) Organizational Support for Change

d. The Influence of Organizational Culture To The Implementation of e-Government

Individual cultural norms and behavior patterns play a role in making policies using technology. Since culture plays an important role in view of the individual, many people resist change and adopt new technologies slowly and with great consideration [8]. Organizational Culture in companies or institutions is widely believed to affect organizational performance and successful implementation of information systems (IS). There is a statistically significant positive correlation between elements of organizational culture as (organizational values, organizational beliefs, organizational norms, and organizational expectations) and e-Management adoption [14].

So that we can conclude that the cultural norms and patterns of behavior that already preconceived will affect the implementation of information systems such as eGovernment in conducting organizational activities among government agencies.

The organizational culture measurement indicator is ( [14], [23] ) :
a) Organizational Trust
b)Organizational Values
c) Organization norms
d) Organizational Hope

\section{e. Effect of Management support on Implementation of $e$ - Government}

The involvement of leadership and integrated vision of IT, it is very important for eGovernment vertical planning, the acquisition of the necessary resources, the motivation of officials, support of agreements with partners and external stakeholders, to inter-agency coordination and ministry. As can be observed in transitional democracies and developing countries, political leadership and integrated vision of IT is what drives the development of e-Government [9].

The management support measurement indicator is ([24], [25] ):
a) support facilities
b)the influence of management
c) authority management
d) interest in use and expertise

\section{f. The Effect of Human Resource Competence on Implementation of e-Government}

Technical skills for the implementation, maintenance, design and installation of ICT infrastructure, as well as the skills to use and manage online processes, functions and customers are mandatory. To overcome the problem of human resource development, knowledge management initiatives needed to focus on staff training to create and develop basic skills for the use of e-Government [26]. So that with the ability possessed by the HR problems problems in the process of information systems can be resolved. 
The measurements of the competencies of the SDM are [27],[28] :
a) Education
b) Training
c) adequate experience
d) Skills

g. The Influence of Information Technology Implementation of E-Government.

The availability of information technology systems, including hardware partitions, databases, software, networks, and other tools used will facilitate e-Government implementation. The infrastructure aspect remains a key challenge for e-Government ( [11], [29] ). Infrastructure is a big challenge because it is seen by prior research [30], [31], [32]), as a significant barrier to the provision of government services and online transactions.

This together with computer security, privacy and confidentiality of private data poses challenges to the application of e-government initiatives ([31], [32]) because most developing countries do not have laws protecting privacy citizens [11].

Indicators of measurement of information technology are ([33],[34]) :
a) Hardware
b) Softwere
c) Data/ database
d) Prosedur
e) Internet/ Network

\section{Hypothesis}

Based on the literature review it is suspected:

H1: There is significant and negative influence of user resistance to implementation of e-government .

$\mathrm{H} 2$ : There is a significant and positive influence of organizational culture on the implementation of eGovernment.

H3: There is a significant and positive influence of management support on implementation of egovernment

H4: There is a significant and positive influence on the competence of tbsp on the implementation of egovernment.

H5: There is a significant and positive influence of information technology on the implementation of eGovernment.

H6: There is a significant and positive influence of implementation of e-Government on Information Quality.

\section{METHOD}

The research was conducted at the local government in Agam District. Data collection was conducted on May 29 June 8, 2018. The population of this study is all employees at the local government OPD Agam District. The study was conducted by distributing questionnaires at 25 cantons in Agam District. Each one district office is given as many as
6 questionnaires related to the purpose of this research, where the questionnaire is addressed to the Chief of Staff, Head of Services, Head of Finance, Head of Information \& Technology, and two service staff at the regional office with total questionnaires spread by 150 copies.

Sampling technique in this research is purposive sampling technique that is selected data based on certain criterion that appropriate with research purpose. The number of samples and questionnaires that can be collected in this study is 119 people from 25 regional offices consisting of 16 official offices, 4 bodies, and 3 districts that can be collected by researchers based on the permit given research.

This research applies Structural Equation Modeling (SEM) approach. This technique can be applied in several forms, first is the path analysis or causal modeling hypothesizing the causal relationship between variables. The second is confirmatory factor analysis that tests the hypotheses about the structure of factor loadings and their interrelations.

\section{RESULTS}

\section{Respondent's characteristic}

Results of research on the characteristics of respondents in view of the gender of male respondents as many as 56 people and women as many as 63 people, meaning that in terms of female sex dominant in this research sample. Respondents based on employment status of civil servants amounted to 100 people and honorer amounted to 19 people, meaning the study sample is dominated by employees / employees who bersatatus PNS. Respondents based on the highest education level in S1 and S2 graduate education qualifications amounted to 91 and 18 people, only 1 person who qualified education S3. The working period of most respondents in more than 10 years.

\section{Descriptive Analysis}

The results of the questionnaire response frequency of respondents showed an average score of 1.9 the variable resistance with TCR of $37.32 \%$. This shows the user resistance is not good which means there is no rejection of a system change..

The results of the questionnaire response frequency of respondents showed an average score of organizational culture variables is 4.1 with TCR of $83.38 \%$. This shows the organizational culture is already quite good.

The results of the questionnaire response frequency of respondents showed an average score of 4.2 management support variable with $83.80 \%$ TCR. This shows that management support is good.

The result of answer frequency questionnaire from respondent showed average score of competence variable of human resources that is 3,9 with TCR equal to $78,99 \%$. This shows the competence of human resources quite adequate.

The result of frequency questionnaire answer from respondent show average score of information technology variable that is 4,2 with TCR equal to $83,52 \%$. This shows information technology is quite good.

Result of frequency answer questionnaire from respondent showed average score of e-Government variable that is 4,2 with TCR equal to $83,87 \%$. This shows information technology is quite good. 
The result of frequency questionnaire answer from respondent showed average score of e-Governmant variable that is 4.0 with TCR equal to $79,81 \%$. This shows information technology is quite good.

\section{Inductive Analysis}

Referring to the literature review and conceptual framework, the empirical models developed by theory and in the estimation are two equations as follows:

$\mathrm{Y}_{1}$ e-governemnt $=\beta 1 R P+\beta 2 B O+\beta 3 D M+\beta S D M+\beta 5 T I+$ e1

$\mathrm{Y}_{2}$ Quality Information $=\beta 1$ e-Government $+\mathrm{e} 2$

The following is an estimate of the complete model of the SEM equation, see figure 1 and Table I :

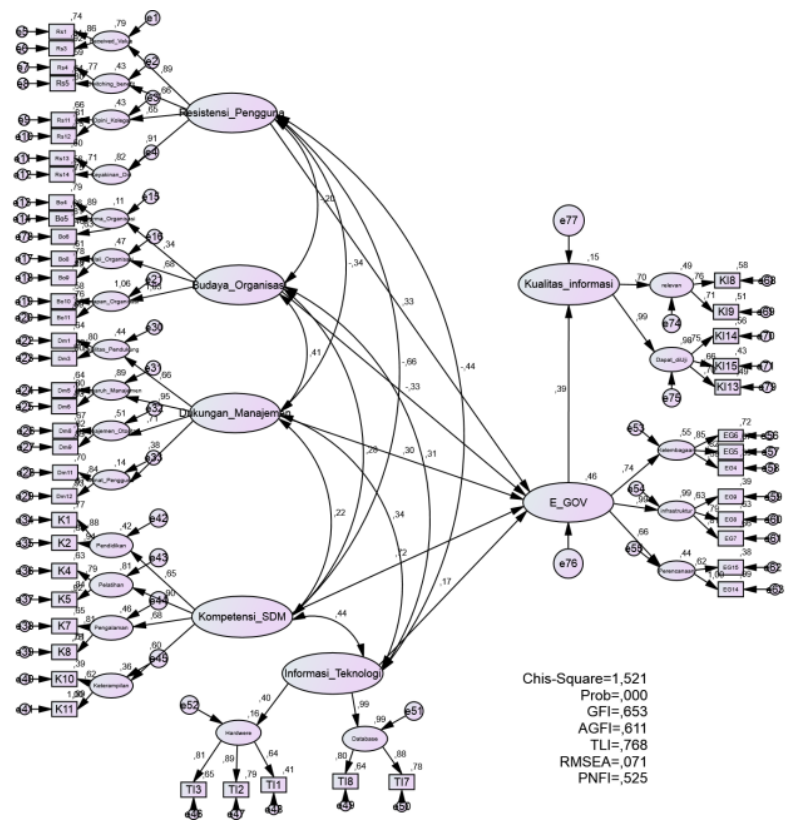

Fig. 1. Full Model SEM

TABLE I. ESTIMATE SEM

\begin{tabular}{|l|l|l|l|l|}
\hline \multicolumn{1}{|c|}{ Variable } & Estimate & C.R & Probability \\
\hline $\begin{array}{l}\text { User Resistance > e- } \\
\text { Government }\end{array}$ & 0.331 & 1.684 & 0.092 \\
\hline $\begin{array}{l}\text { Organizational culture > e- } \\
\text { Government }\end{array}$ & -0.332 & - & 0.085 \\
\hline $\begin{array}{l}\text { Management Support > e- } \\
\text { Government }\end{array}$ & 0.301 & 1.724 & 0.060 \\
\hline $\begin{array}{l}\text { Human Resources } \\
\text { Competencies > e-Government }\end{array}$ & 0.717 & 2.924 & 0.003 \\
\hline $\begin{array}{l}\text { Information Technology > }> \\
\text { Government }\end{array}$ & 0.174 & 1.149 & 0.251 \\
\hline e- Government > Information & 0.387 & 2.514 & 0.012 \\
Quality & Result & Index & \\
\hline God-of-fit & 1.521 & & \\
\hline Chi-Square & 0.000 & $>0.05$ & \\
Prob & 0.653 & $>0.90$ & \\
GFI & 0.611 & $>0.90$ & \\
AGFI & 0.768 & $>0.90$ & \\
TLI & 0.071 & $<0.08$ & \\
RMSEA & 0.521 & 0 & - & \\
PNFI & & 1.0 & \\
\hline
\end{tabular}

Interpretation of the results can be explained as follows:

a) The estimated value of God-Of-Fit based on the equation model which has been hypothesised previously shows results far from the achievement index of criteria which have been determined where; The value of $\neg$ ChiSquare $=1.521$, prob $=0.000$ with the index specified should be $>0.05$, the result of GFI $=0.653$ with the specified index should be $>0.90$, the estimation result of AGFI $=0.768$ with index $>0.90$ and the estimation result RMSEA 0.751 with index $>0.05<0.08$. so that with the absence of the God-Of-Fit criterion the equations model is hypothesized to be less precise and produces a biased research model. Modification of the model should be done in order to get an estimate that reaches God-Of-Fit with unbias estimates.

b) The estimated value of user resistance parameter to eGovernment is 0.331 with C.R or $\mathrm{t}_{\text {count }} 1.684<\mathrm{t}_{\text {tabel }} 1.984$ and probability $=0.092>0.05$, this can be interpreted there is no significant and negative influence between user resistance to e- Government.

c) The estimated value of organizational culture parameter to e-Government is -0.332 with C.R or $t_{\text {count }}-1.724<$ $\mathrm{t}_{\text {tabel }} 1.984$ and probability $=0.085>0.05$, it can be interpreted there is no significant and positive influence between organizational culture to e- Government.

d) The value of management support parameter estimation to e-Government is 0.301 with C.R or $\mathrm{t}_{\text {count }} 1.879<\mathrm{t}_{\text {tabel }}$ 1.984 and probability $=0.060>0.05$, this can be interpreted there is no significant and positive influence between organizational culture to e- Government.

e) The estimated value of human resource competency parameter to e-Government is 0.717 with C.R or $t_{\text {count }}$ $2,924>\mathrm{t}_{\text {table }} 1,984$ and probability $=0.003<0.05$, this can be interpreted there is significant and positive influence between Human Resource Competence to eGovernment.

f) The estimated value of Information Technology parameter to e-Government is 0.174 with C.R or $t_{\text {count }}$ $1.149<\mathrm{t}_{\text {tabel }} 1.984$ and probability $=0.251>0.05$, it can be interpreted there is no significant and positive influence between information technology to eGovernment.

g) The value of e-Government parameter estimation on the quality of information is 0.387 C.R or $t_{\text {count }} 2,514<\mathrm{t}_{\text {tabel }}$ 1.984 and with probability $=0.012<0.05$, it can be interpreted there is a significant and positive influence between e- Government Against the quality of information.

This estimation result based on hypothetical equation model can not make final result because God-Of-Fit value has not been realized yet. So the model that has been determined to be modified model to get a model structure that achieve the normal distribution of data, no data outlier and fulfillment God-Of-Fit so that the results of this study can be explained well and unbias.

In AMOS 22 has provided estimation in modifying the model. Modified model is called Modification Indices. The results of the latest model modifications will yield new model equations in measuring endogenous variables. The estimation results can be seen in Figure 2 dan Table II. 


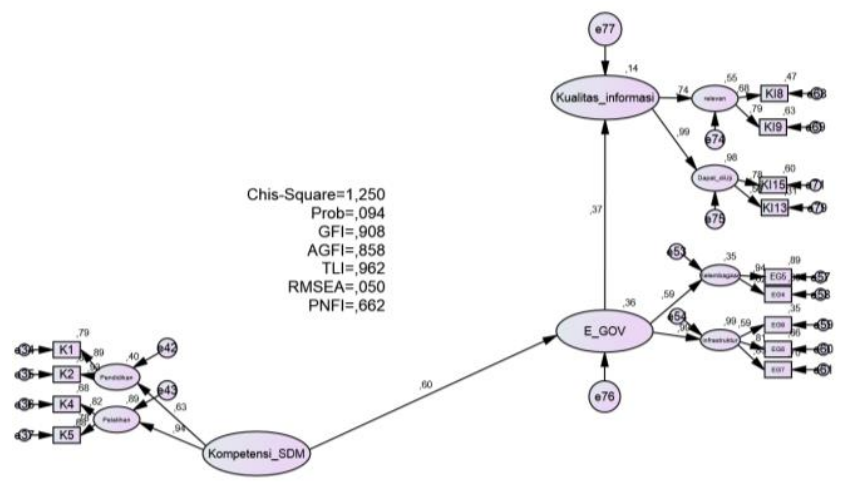

Fig. 2. Estimate Modifiaction Model

TABLE II. ESTIMATE SEM

\begin{tabular}{|l|c|c|c|}
\hline \multicolumn{1}{|c|}{ Variable } & Estimate & C.R & Probability \\
\hline HR > e- Government & 0.600 & 2.765 & 0.006 \\
\hline e- Government $>$ & 0.371 & 2.302 & 0.042 \\
Informasion Quality & & & \\
\hline God-of-fit & Result & Index & \\
\hline Chi-Square & 1.250 & & \\
Prob & 0.094 & $>0.05$ & \\
GFI & 0.908 & $>0.90$ & \\
AGFI & 0.858 & $>0.90$ & \\
TLI & 0.962 & $>0.90$ & \\
RMSEA & 0.050 & $<0.08$ & \\
PNFI & 0.662 & 01.0 & \\
\hline
\end{tabular}

Interpretation of the results can be explained as follows:

a) The result of God-Of-Fit value estimation based on hypothetical equation model shows much better result with the achievement of predetermined God-Of-Fit index where; Value of Chi-Square $=1.250$, prob $>0.094$ with index $>0.05$, GFI result $=0.908$ with index $>0.90$, and result of RMSEA 0,050 with index $>0.05<0.08$. so that with the absorption of six index criteria God-Of-Fit is the value (1) Chi-Square, (2) probability, (3) GFI, (4) TLI, (5) RMSEA, (6) PNFI. This means that the hypothesized equation model is appropriate and produces an unbias research model. The new research model equations are:

$\mathrm{Y}_{1} \mathrm{e}$-governemnt $\quad=\beta S D M+\mathrm{e} 1$

$\mathrm{Y}_{2}$ Information Quality $=\beta 1$ e-Government

b) The estimated value of human resource competence parameter to e-Government is 0.600 with C.R or $t_{\text {count }}$ $2.765>\mathrm{t}_{\text {table }} 1.984$ and probability $=0.006<0.05$, this can be interpreted there is a significant and positive influence between human resource competence to eGovernment. This means that if the value of competence variables increased by one unit of human resources will increase the value of e-Government variables of 0.600 .

c) e-Government value estimation value for information quality is 0.371 with C.R or $t_{\text {count }} 2.032>t_{\text {table }} 1.984$ and probability $=0.042<0.05$, this can be interpreted there is a significant and positive influence between eGovernment on the quality of information. This means that if the value of e-Government variables increase one unit it will increase the value of information quality variable of 0.371 . d) The latent variables or constructs of exogenous and endogenous variables are all valid indicators with values $\alpha>0.50$.

\section{Coefficient of Determination (R2)}

TABLE III. COEFFICIENT OF DETERMINATION (R2)

\begin{tabular}{|l|l|}
\hline \multicolumn{1}{|c|}{ Endogen Variable } & Estimate \\
\hline e- Government & 0.360 \\
\hline Quality Informasion & 0.137 \\
\hline
\end{tabular}

In table 3 we can see the effect of exogenous variables on endogen. In e-Government variables the effect of exogenous variables is 0.360 or $36 \%$ means in addition to the influence of competence variable of human resources there are many other variables that affect equal to $64 \%$ variable eGovernment. Value for variable quality of information influenced by exogenous variables is 0.137 or $13.70 \%$ meaning in addition to e-Government influence there are many other variables affecting $86.30 \%$ variable quality information.

\section{DISCUSSION}

a. The Influence of User Resistance Against Implementation of e-Government

The results of statistical data analysis proves that there is no influence of the resistance against the implementation of eGovernment (C.R or 1,684 $\mathrm{t}_{\text {count }}<\mathrm{t}_{\text {table }} 1,984$ and probabiliy of 0.092> 0.05), then Ho is accepted and Ha rejected. This means that users do not have a variable resistance be one of the factors that affect the application of e-Government in Agam district administration.

The results of this study are not in line with Hierchheim and Newman, [35] who explain resistance is a reaction that contradicts the proposed change. Contradiction can be overtly expressed in the form of sabotage, or as quietly as running but grumbling or criticizing the new system. According to Markus [36] resistance is a reaction opposite to the changes perceived by the user on the implementation of new information systems. The results of this study also does not support [37] study which says that the indicators that become the measure of user resistance can affect the application of new information systems.

The result of the research test is supported by descriptive analysis which shows that the Respondents Response Level on the variable of user resistance with the average score of 1.9 variables with TCR of $37.32 \%$. This shows the user resistance is not good which means there is no rejection of a system change. Respondents said that with changes to the information system will make the work to be effective, do not consider the complexity of change and the support of the organization in the change of information systems.

\section{b. The Influence of Organizational Culture to} Implementation of e-Government

The result of statistical data analysis proves that there is no influence of organizational culture towards the implementation of e-Government (C.R or $\mathrm{t}_{\text {count }} 1.724<\mathrm{t}_{\text {tabel }}$ 
1.984 and probabiliy of $0.092>0.05$ ), meaning Ho accepted and $\mathrm{Ha}$ rejected. This means that variable of organizational culture does not become one of the factors that affect the application of e-Government in Agam district.

The results of this study do not support Naser [14] which says Organizational Culture in companies or institutions widely believed to affect the performance of the organization and the successful implementation of information systems (IS). There is a statistically significant positive correlation between elements of organizational culture as (organizational values, organizational beliefs, organizational norms, and organizational expectations) and e-Management adoption. Feng [38] also explained that culture plays an important role in the views of individuals, many people resist change and adopt new technologies slowly and with great consideration.

The result of the research test is supported by descriptive analysis showing the respondent's performance level with the average score of 4.1 with TCR of $83.29 \%$. This shows the organizational culture is quite good. Organizational culture in the district of religion that is classified as good this shows the creation of a work culture such as the participation of employees in decision-making, employees exchange information and employees have responsibility for their work.

\section{c. The Influence of Management Support to} Implementation of e-Government.

The result of statistical data analysis proves that there is no influence of management support to the implementation of e-Government (C.R or $\mathrm{t}_{\text {count }} 1.724<\mathrm{t}_{\text {tabel }} 1.984$ and probabiliy of 0.092> 0.05), meaning Ho accepted and Ha rejected. This means that variable of organizational culture does not become one of the factors that affect the application of e-Government in Agam district.

The results of this study do not support the opinion of Alshehri [39] which says leadership engagement, as well as the unified vision of IT, is essential for vertical e-Government planning, the acquisition of necessary resources, the motivation of officials, the support of agreements with partners and external stakeholders, to inter-agency and ministerial coordination.

The result of the research is supported by descriptive analysis which shows the average score of management support variable is 4.0 with TCR of $79.58 \%$. This shows good management support, management support such as management involvement is actively organized in the development of information systems. Management provides training for the use of new information systems and employees show an interest in system changes.

\section{d. The Influence of Human Resource Competence to Implementation of e-Government}

The result of statistical data analysis proves in the second equation model that there is influence of human resource competence on the implementation of e-Government (C.R or $\mathrm{t}_{\text {count }} 2,765<\mathrm{t}_{\text {tabel }} 1.984$ and probabiliy of $\left.0.006<0.05\right)$, Ha is accepted and $\mathrm{H} 0$ rejected. Estimated value also shows if the value of competence variable of human resources increased by one unit then it will increase the value of e-Government variable of 0.600 . This means that the competency variable of human resources become one of the factors that influence the implementation of e-Government in Agam district.

This research supports OECD [26] which says technical skills for the implementation, maintenance, design and installation of ICT infrastructure, as well as skills to use and manage online processes, functions and customers are mandatory. To address the issue of human resource development, knowledge management initiatives are needed focusing on staff training to create and develop basic skills for e-Government use.

The result of the research is supported by descriptive analysis which shows the average score of competence variable of human resources is 3.8 with TCR of $75.29 \%$. This shows the competence of human resources quite sufficient. Based on the answers of the respondents training in improving the competence of human resources is still quite included, including training in accordance with the information system. Experience in the field of information systems is also still quite enough, as well as skills in providing public services based on IT is still quite enough.

\section{e. The Influence of Information Technology to $e$ - Implementation of Government}

The result of statistical data analysis proves that there is no influence of information technology on the application of e-Government (CR or tcount $1.149<$ ttabel 1.984 and probabiliy of $0.251>0.05)$, H0 is accepted and Ha rejected .. It means that the variable of Information Technology not become one factor affecting the implementation of e-Government in Agam district.

The results of this study do not support Ndou [11] which explains aspects of infrastructure that become the main challenge for e-Government e-Government. Unreliable IT infrastructure will further influence to degrade e-government performance from their respective governments [29]

The result of the research is supported by descriptive analysis which shows the average score of information technology 4.2 with TCR of $82.52 \%$. This shows information technology is quite good. Each OPD already has Hardware and softwere to implement information systems and output devices in doing the work. Networks are already available in connecting multiple computers like good internet.

\section{f. The Influence Implementation of e-Government to Information Quality}

The result of statistical data analysis on equation model proves that there is influence of e-Government application on the quality of information (C.R or $t_{\text {count }} 2.302>t_{\text {tabel }} 1.984$ and probabiliy of $0.042<0.05)$, Ha is accepted and $\mathrm{H} 0$ is rejected. Estimated value also shows if the value of e-Government variable increased by one unit it will increase the value of information quality variable of 0.371 . This means that eGovernment variables become one of the factors that affect the quality of information in the Agam district.

The results of this study support the explanation Dellon \& McLean [18] said the success of information systems to measure the output generated by the system. Furthermore, the success of the model includes six components of the success of information systems namely, System Quality, Quality Information, Usability, User Satisfaction, Individuals, 
Organization. Baltzan [3] revealed Information Integrity is a measure of the quality of information. Integrity constraints are rules that help Ensure information quality. Factors affecting the adoption of e-government websites are quality of information, system quality and service quality. Quality of information relates to the size of the information the system generates [19].

The result of the research test is supported by descriptive analysis which shows the average score of e-Governmant variable is 4.2 with TCR of $83.87 \%$. This shows egovernmant quite good. Each regional office has a form of decision, regulation or discretion about applying the information system. Each regional office has a good organizational structure to carry out the functions and technical information systems. Each regional office has a supporting infrastructure and has an information system or application in serving the community.

\section{CONCLUSION}

Based on the results of research and discussion can be concluded that there is a positive and significant influence of human resource competence on the implementation of eGovernment. However, there is no positive and significant influence on user resistance, organizational culture, management support, and information technology on eGovernement implementation. The results also show that there is a positive and significant influence of e-Government applications on information quality. Human resource competence is an important factor affecting the implementation of e-Government to produce good information quality at local government of Kabupaten Agam The better the implementation of e-Government through institutional and infrastructure will result in the quality of information that is relevant and tested. The results of this study will contribute to the improvement of information systems in the district government of kabupaten agam and science related to information systems.

\section{REFERENCE}

[1] BPPTIK. Urgensi Pengembangan SDM Bidang TIK untuk ASN di Seluruh Indonesia. bpptik.kominfo.go.id. 2016.

[2] Aptika. Gempita (Gema Publikasi Aptika). Kominfo.go.id. 2015.

[3] Baltzan. Business Driven Information Systems. Third Edit. New York: McGraw Hill. International Edition.; 2012.

[4] Agarwal P. Portals: the path to everything," Government Technology. www.govtech.net,. 2000.

[5] Brosey, W.D et all. Grand Chalenges Of Enterprise Integration. Tenesse Y-12 Natl Secur Complex. 2001.

[6] Kent Sandoe, Gail Corbitt RB. Enterprise Integration. ohn Wiley Sons,Inc. 2001.

[7] Kim H-W, Kankanhalli. Investigating User Resistance to Information Systems Implementation: A Status Quo Bias Perspective. MIS Q. 2009; vol.33, no:hal. 567-82.

[8] Feng. Implementing E-government Strategy is Scotland: Current Situation and Emerging Issues. J Electron Commer Organ. 2003.

[9] Alshehri, Mohammed, Drew S. E-Government Fundamentals. Proc IADIS Int Conf ICT, Soc Hum Beings. 2010.

[10] Akbulut A. An investigation of the factors that influence electronic information sharing between state and local agencies. Louisiana State Univ. 2003.
[11] Ndou. E-government for developing countries: opportunities and challenges. Electron J Inf Syst Dev Ctries. 2004.

[12] UNPA \& ASPA. Benchmarking e-Government: A Global Perspective [Internet]. Available from: http://unpan1.un.org/intradoc/groups/public/documents/un/unpan00398 4.pdf

[13] Yousef, Almarabeh T, Mohammad H, Quteshate W. E-Government Strategy and Plans in Jordan. 2015;(April):211-23.

[14] Naser. The Impact of Organizational Culture on the Adoption of EManagement "Evidence from Public Authority for Applied Education and Training ( PAAET ) in Kuwait ." 2014;9(9):57-74.

[15] Jogiyanto. Sistem Teknologi dan Informasi. Yogyakarta: AndiYogyakarta; 2000.

[16] O'Brien. Introduction to Information System. Edition. M. 2015.

[17] Krismiaji. Sistem Informasi Akuntansi. Yogyakarta: AMP YKPN; 2002.

[18] DeLLone, McLean. Model of Information Systems Success: A TenYearUpdate. J Manag Inf Syst. 2003;9-30.

[19] Safeena, Kammani A. Conceptualization Of E-Lectronic. Int J Manag Inf Technol. 2013;5(1)

[20] Heeks R. Most e-government for Development Project Fail: How Can Risk be Reduced?. iGovernment Working Paper Series. Manchester Inst Dev Policy Manag. 2003.

[21] Bank TW. A Definition of EGovernment. http://www1.worldbank.org/publicse ctor/egov/definition.htm. 2001

[22] E-Government D. Pemeringkatan e- Government Indonesia (PeGI) Tingkat Provinsi Tahun 2011. Dirjen Aptika Kemenkominfo. 2011.

[23] Besha T, Negash S. The Impact of Organizational Culture on IS Implementation Success in Ethiopia: the Case of Selected Public and Private Organizations The Impact of Organizational Culture on IS Implementation Success in Ethiopia: the Case of Selected Public and. 2009.

[24] Harlinda. Effect of management support and user participation on implementation of information systems success and undergraduate programs performance. Int J Eng Sci. 2017.

[25] Sharma, R. and Yetton P. The contingent effects of management support and task interdependence on successful information systems implementation. MIS Q. 2003.

[26] OECD. OECD E-Government Flagship Report "The E-Government Imperative,. Public Manag Committee, ParisOECD. 2003.

[27] Iskandar. The Influence Of Human Resources Competency And The Use Of Information Technology On The Quality Of Local Government Financial Report With Regional Accounting System as an Intervening. 2017;95(20)

[28] Ward, Peppard. Strategic Planing For Information System. 2002.

[29] Ebrahim, Irani. E-government adoption: architecture and barriers. Bus Process Manag J. 2005.

[30] Bonham, Seifert J, Thorson S. The transformational potential of egovernment: the role of political leadership. Pap Present 4th Pan Eur Int Relations Conf. 2001;

[31] McClure D. Electronic Government: Challenges Must Be Addressed with Effective Leadership and Management. GAO-01-959T, Testimony before the Senate Committee on Governmental Affairs, on behalf of the U.S. General Accounting Office. http//www.gao.gov/new.items/d01959t.pdf, Accessed 8/10/2009. 2001.

[32] Gefen. E-government adoption. Pap Present Am Conf Inf Syst Tampa, FL. 2002.

[33] Taiwon. Effect of ICT on Accounting Information System and Organisational Performance. Eur J Bus Soc Sci. 2016.

[34] Zadeh. The Effect of Information Technology on the Quality of Accounting Information. 2015;3(3):61-76.

[35] Hierchheim, Newman. Information Systems and User Resistance: Theory and Practice. Comput J. 1988;vol. 31, n:hal. 398-408.

[36] Markus ML. Power, Politics, and MIS Implementation. Commun ACM. 1983; vol. 26, n:hal. 430-44.

[37] Siregar. Hubungan Antara Dividen, Leverage Keuangan, dan Investasi. J Akutansi Manaj. 2005;Vol. 16 No:hlm. 219-30.

[38] L. F. Implementing E-government Strategy is Scotland: Current Situation and Emerging Issues. J Electron Commer Organ 1(2), 44-6. 2003. 
[39] Alshehri M, Drew S. E-Government Fundamentals Author. 2010. 